ROCZNIKI PEDAGOGICZNE

Tom 11(47), numer specjalny - 2019

DOI: http://dx.doi.org/10.18290/rped.2019.11s-11

ZBIGNIEW GOSPODAROWICZ

\title{
EWOLUCJA DOKTRYNY OCHRONNEJ \\ - WYMUSZONA ZEWNĘTRZNIE KONIECZNOŚĆ \\ CZY ŚWIADOMY PROCES HUMANIZACJI
}

Zgodnie z tym, co wskazały w komentarzu do Europejskich Reguł Więziennych Danuta Gajdus i Bożena Gronowska (1998, s. 53), więziennictwo ma dwa zasadnicze oblicza: osoby pozbawione wolności oraz kadrę więzienną. Wszelkie zmiany zachodzące w więziennictwie muszą więc przebiegać dwutorowo, uwzględniając specyfikę obu tych grup społecznych. Koniecznością pozostaje podejmowanie permanentnych działań na rzecz zachowania właściwych proporcji między tymi dwiema kategoriami podmiotów.

Właściwości osobiste osób pozbawionych wolności, na początkowym etapie pobytu w izolacji, pozostają poza sferą wpływu Służby Więziennej. Tym większego znaczenia nabierają więc działania skierowane na ukształtowanie profesjonalnej, zdolnej do podejmowania nowych wyzwań kadry penitencjarnej, gotowej zrozumieć potrzebę otwarcia na drugiego człowieka i poświęcenia dla jego przemiany umiejętności zawodowych i walorów osobistych.

We wspomnianych już Europejskich Regułach Więziennych wskazano, że administracja więzienna ma obowiązek troski o staranny dobór całego personelu do służby przygotowawczej i stałej, kładąc szczególny nacisk na jego prawość, ludzkie podejście, umiejętności zawodowe oraz cechy osobowe przydatne w zawodzie. Humanitarny wydźwięk reguł świadczy o przekonaniu jej twórców o przewadze metod perswazyjnych nad metodami uciskowymi i restrykcyjnymi. Tylko pełna akceptacja takiego podejścia może stanowić, podstawę ideologiczną dla realizacji współczesnej polityki bezpieczeństwa

Płk Zbigniew Gospodarowicz - Dyrektor Biura Ochrony i Spraw Obronnych Centralnego Zarządu Służby Więziennej, ul. Rakowiecka 37a, 02-521 Warszawa; e-mail: Zbigniew.Gospodarowicz@sw.gov.pl 
jednostek penitencjarnych. Taka perspektywa nie zmienia faktu, że dogmatem pozostaje konieczność zapewnienia bezpieczeństwa osobistego i korporacyjnego wszystkim uczestnikom procesów realizowanych w zakładach karnych.

Ustalenie, jaki jest obecnie stan kadry ochronnej, wymaga wskazania, jak głębokie zmiany zaszły w jej strukturze w latach dziewięćdziesiątych minionego stulecia, których podłożem były przemiany ustrojowo-społeczne. Ryszard Musidłowski (1997, s. 35) w I części opracowania „Stan i węzłowe problemy polskiego więziennictwa" wskazał, że w okresie około dwóch lat ze służby odeszło ponad 7000 funkcjonariuszy. Dziś nikt już nie pamięta atmosfery tamtej, jak to nazywano, „wielkiej zmiany”. Warto jednak dalej za Musidłowskim zauważyć, że „do odejścia ze służby namawiało ówczesne kierownictwo”, zaś potrzebę wymiany kadrowej uzasadniano „koniecznością odzyskania władzy moralnej”.

Pozostawiając ten obszar bez oceny, trzeba wskazać na materiały z konferencji penitencjarnej zorganizowanej w 1995 roku w Kaliszu. Z danych zawartych w tych materialach wynika, że na początku lat 90 . zmieniła się cała dyrekcja Centralnego Zarządu Służby Więziennej oraz naczelnicy wszystkich jego wydziałów, wymieniono także około $70 \%$ naczelników zakładów karnych i aresztów śledczych. Procesy, które zaszły, miały zasadnicze znaczenie dla możliwości wprowadzania zmian, otwierania nowych kierunków oraz podejmowania działań w obszarach, w których ich realizacja, bez tak głębokich zmian kadrowych, byłaby niewątpliwie znacznie utrudniona.

Warto zwrócić także uwagę na społeczny odbiór więziennictwa w początkowym okresie przemian. Problemem, wtedy bardzo widocznym i niestety dotykającym formację także obecnie, jest przekonanie znacznej części społeczeństwa, że środki przekazywane na funkcjonowanie Służby Więziennej powinny skutkować brakiem jakichkolwiek problemów od struktury dla tego społeczeństwa. Służba Więzienna wzbudza zainteresowanie medialne prawie wyłącznie w przypadkach wystąpienia zdarzeń ewidentnie odbieranych jako błąd w realizacji zadań statutowych. Przykładem, który w efekcie wpłynął na podejmowanie działań zmieniających sposób myślenia o ochronie jednostek, było zdarzenie zabójstwa przez strażnika więziennego przebywających w jednostce penitencjarnej funkcjonariuszy Policji czy choćby spektakularne samobójstwa osób powszechnie uznawanych za istotne dla wymiaru sprawiedliwości.

Przeprowadzone zmiany kadrowe, zdarzenia nadzwyczajne, wpływ opinii publicznej na więziennictwo skutkowały wytworzeniem atmosfery potrzeby zmiany. Na V Kongresie Penitencjarnym wprost wyraził to ówczesny dyrektor Biura Ochrony i Spraw Obronnych płk Marian Puszka (2015, s. 189). W swoim referacie „System ochrony polskich jednostek penitencjarnych. Poszukiwanie optymalnego modelu” wskazał, że „dotychczas nie poddano dogłębnej, 
krytycznej analizie całokształtu funkcjonowania służby ochronnej”. W literaturze przedmiotu jedynie w niewielkim zakresie zagadnienia ochronne leżą w spektrum badań naukowych, a przecież wiele obecnie stosowanych w ochronie rozwiązań i mechanizmów korzeniami sięga głębokiej przeszłości, zachowując ogromną rezystancję na próby podejmowania działań reformatorskich. Presja części środowiska na konieczność przeprowadzenia rzeczywistych zmian prowadziła w efekcie do pozoracji w tym zakresie, ograniczając je do kosmetyki.

Przedstawione stanowisko, pozostając ewidentnie słuszne i trafione, na etapie jego publikacji nie było już jednak w pełni aktualne. Środowisko ochronne dojrzało już do wprowadzenia zmian, było na nie gotowe i nie wykazywało wspomnianej rezystancji na działania reformatorskie. Był to czas, kiedy nie było już potrzeby przekonywania do zmiany systemu o charakterze łagrowym, opartym na posterunkach uzbrojonych i psach służbowych, na system otwarty na drugiego człowieka i nakierowany na osiągnięcie celów izolacji penitencjarnej oraz humanitarnego rozwiązywania bieżących problemów i trudności. Oddzielną kwestią pozostawało wskazanie najskuteczniejszej drogi dla wdrożenia w codziennej praktyce przyjętych rozwiązań.

Nie można zapominać, że przemiany społeczne to także zmiany w strukturze przestępczości. Na terenie jednostek pojawiają się zorganizowane formacje przestępcze, gotowe dla ochrony własnych interesów dopuszczać się czynów zabronionych, nawet tych z pogranicza zbrodni. Przypadki zastraszania funkcjonariuszy, informowania przestępców o miejscu ich zamieszkania czy też o sytuacji rodzinnej były niestety dość powszechne, a jednocześnie w zasadzie niemożliwe do udowodnienia i tym samym skutecznego ścigania. Atmosfera pracy w tym okresie była zdecydowanie trudna. Część kadry wprost wskazywała, że najwłaściwszym antidotum na nowe zagrożenia byłby powrót do metod poprzedniego systemu - zaostrzenie dyscypliny do granic praworządności, co często wiązało się z przekroczeniem tych granic. Grupa ta była w zasadniczej mniejszości. Zdecydowana większość kadry ochronnej była w pełni świadoma, że zaistniałe zmiany wykluczają powrót do stosowanych w przeszłości metod i rozwiązań. Jedynym natomiast skutecznym rozwiązaniem problemów zagrożenia bezpieczeństwa musi być poszukiwanie nowej formuły lub głęboka zmiana formuły obecnie stosowanej.

$\mathrm{Na}$ wskazane już trudności nałożyły się także inne problemy wynikające z codziennej rzeczywistości więziennej i społecznej. Można tu wskazać chociażby zjawisko HIV/AIDS, na które w początkowym okresie służba była zupełnie nieprzygotowana. W tym samym obszarze znajduje się kwestia tajemnicy zdrowia. Zagadnienie wdrożono, nie poprzedzając go odpowiednim 
przygotowaniem funkcjonariuszy, ale także wyposażeniem ich w odpowiednie środki ochrony osobistej.

Niestety nowe zjawiska szły w parze z pogłębiającymi się trudnościami natury finansowej. W jednostkach brakowało dosłownie wszystkiego. Potrzeby ochronne zeszły na dalszy (ostatni) plan, poza wszelkie działania związane z zapewnieniem bieżącego bytu jednostek. W takim środowisku należało opracować możliwe do wdrożenia działania pozwalające podnieść poziom bezpieczeństwa i skuteczność realizacji zadań ochronnych.

Logicznym kierunkiem wydawało się wzmocnienie ochrony wewnętrznej. Źródłem zasobów kadrowych, możliwym na tamtym etapie do wykorzystania, były posterunki uzbrojone. Nie bez oporów nakłaniano kierowników jednostek organizacyjnych do ich likwidacji na rzecz wparcia technicznego i elektronicznego. Wprowadzono metodę wsparcia finansowego dla tego typu projektów. Przyjęty model okazał się zaskakująco skuteczny. Ze względu na specyfikę jednostek penitencjarnych należy jednak przyjąć, że do końca (likwidacja wszystkich posterunków uzbrojonych) nigdy nie zostanie doprowadzony.

W obszarze edukacyjnym tego projektu wykorzystano zmiany w prawie karnym dotyczące eliminacji kary śmierci (Pierzchała, 2008). Kadrze zarządzającej średniego szczebla permanentnie uświadamiano, że nie można budować systemu bezpieczeństwa, opierając się na założeniu fizycznej eliminacji więźnia. Odbiurokratyzowano codzienną działalność ochronną, uproszczono przepisy, wyeliminowano zbędną dokumentację. Wzmocniono system nadzoru bezpośredniego oraz monitorowego, odstępując, gdzie to tylko możliwe, od powielania „papierowych”, często wykonywanych bezrefleksyjnie czynności.

Bezpośrednią reakcją formacji na brutalizację świata przestępczego i jego zorganizowania na terenie jednostek było utworzenie Grup Interwencyjnych Służby Więziennej. Formacja stanowi obecnie bardzo istotny element bezpieczeństwa.

Na wysokości zadania stanęły ośrodki edukacyjne. Poziom współpracy i otwartości na oczekiwania decydentów skutkował elastycznymi zmianami w modelu edukacji. Założenia programowe dostosowywano do realizowanych projektów i zadań. Można uznać, że ostatnim obecnie realizowanym w tym obszarze projektem pozostaje powołanie do funkcjonowania akademii Służby Więziennej.

Ważnym, w pewien sposób spinającym prezentowany proces elementem pozostaje kwestia ustanowienia i wdrożenia ustawy modernizacyjnej. Zawarte w niej wymagania w sposób dotychczas niespotykany unowocześnią całą służbę ochronną. Realizacja ustawy spowoduje wymianę prawie całego asortymentu uzbrojenia oraz wdroży proces stałej technologicznej wymiany sprzętu, wynikającej z określonego czasu eksploatacji, a nie jak często obecnie - całkowitego 
zużycia. Ilość sprzętu ochrony osobistej wprowadzonego do systemu w ciągu najbliższych dwóch lat pozwoli zaspokoić potrzeby związane z zapewnieniem bezpieczeństwa funkcjonariuszom formacji ochronnej oraz utrzymaniem porządku i bezpieczeństwa w jednostkach. Modernizacja przyczyni się również do skuteczniejszego realizowania zadań związanych ze współczesnymi wyzwaniami, jak chociażby walka z narkotykami czy dopalaczami.

Co zatem determinowało ewolucję penitencjarnej doktryny ochronnej? Wydaje się, że określenie jednego podstawowego czynnika jest niemożliwe i byłoby logicznym błędem. Proces zmian przebiegał w wielu obszarach i wielotorowo. Wpływały na niego procesy społeczne zachodzące w skali ogólnopolskiej czy nawet szerszej - ze względu na europejskie czy światowe standardy ochrony praw człowieka. Najtrafniejsze jest przyjęcie, że zmiana doktryny ochronnej to wynik zarówno presji społecznej, jak i diagnozy prawdy, która wskazuje, że kadra służby więziennej miała i nadal ma potencjał zmiany. Jest gotowa odpowiadać na wyzwania współczesnej resocjalizacji oraz oczekiwania społeczne, kierowane pod adresem Służby Więziennej. Wiele tych zagadnień analizuje i opisuje wieloletni kapelan więzienny Kazimierz Pierzchała (2011; 2013; 2015a; 2015b; 2016; 2017). Oczywiście jest wielu innych praktyków i teoretyków w tej dziedzinie, z którymi można się zgadzać lub nie, ale prowadzenie dyskursu jest koniecznością.

\section{BIBLIOGRAFIA}

Gajdus, D., Gronowska, B. (1998). Europejskie standardy traktowania więźniów. Toruń: TNOiK. MusidŁowski, R. (1997). Stan i węzłowe problemy polskiego więziennictwa (cz. 1). Biuletyn Informacyjny RPO, 32, 35.

Pierzchąa, K. (2008). Kara śmierci w aspekcie prawnym i etyczno-moralnym. W: K. PierzChala, Cz. CeKIERA, Zwalczanie patologii spolecznych w systemie penitencjarnym Polski i USA. Toruń: Wydawnictwo Adam Marszałek.

PierzchaŁa, K. (2011). Przestępstwo. Probacja alternatywą dla kary pozbawienia wolności. Probacja, 4, 5-26.

PierzchaŁa, K. (2013). Kapelan więzienny w procesie resocjalizacji penitencjarnej. Toruń: Wydawnictwo Adam Marszałek.

PierzchaŁA, K. (2015a). Skazani ale nie potępieni. Wyd. II rozszerzone. Toruń: Wydawnictwo Adam Marszałek.

Pierzchata, K. (2015b). The Process of Social Reintegration of Convicts on the Background of World Penitentiary System. The Analytical and Synthetic Outline of the Issue. [Proces readaptacji społecznej skazanych na tle światowego systemu penitencjarnego. Zarys analityczno-syntetyczny zagadnienia]. Polskie Towarzystwo Nauk Politycznych i Polska Akademia Nauk. Polish Political Science. Yearbook, 44, 154-170. 
PierzchaŁa, K. (2016). Destygmatyzacja przestępców w świetle Magisterium Kościoła oraz poglądów na resocjalizację. Kraków: Oficyna Wydawnicza „Impuls”.

Pierzchąa, K. (2017). Pedagogical and Theological Reflections on the De-Stigmatization Process. [Refleksje pedagogiczno-teologiczne nad procesem destygmatyzacji]. Polish Journal of Social Rehabilitation / Resocjalizacja Polska, 13, 17-37.

Puszka, M. (2015). System ochrony polskich jednostek penitencjarnych, poszukiwanie optymalnego modelu. W: T. Bulenda, A. Rzepliński (red.), Modernizowanie więziennictwa. V Kongres Penitencjarny. Warszawa: Centralny Zarząd Służby Więziennej.

\section{EWOLUCJA DOKTRYNY OCHRONNEJ - WYMUSZONA ZEWNĘTRZNIE KONIECZNOŚĆ CZY ŚWIADOMY PROCES HUMANIZACJI}

\section{Streszczenie}

Tematem artykułu jest analiza ewolucji doktryny systemu penitencjarnego w kontekście przemian ustrojowych, jakie zaszły w Polsce na początku lat dziewięćdziesiątych. W szczególności autor zwraca uwagę na fakt, że wprowadzane zmiany powinny uwzględniać dwutorowy charakter systemu penitencjarnego, który obejmuje dwie grupy podmiotów: osoby osadzone oraz osoby nadzorujące. W artykule odwołano się do założeń współczesnej doktryny penitencjarnej, która kładzie nacisk na humanitaryzm w odniesieniu do osób osadzonych, co znajduje odzwierciedlenie w doborze oraz przeszkoleniu kadry penitencjarnej. Autor skonfrontował założenia teoretycznie z realiami okresu przemian ustrojowych w Polsce na początku lat dziewięćdziesiątych: istotną redukcją w zasobach kadrowych, ograniczeniami finansowymi, zmianami w strukturze przestępczości oraz odbiorem społecznym służby więziennictwa.

Słowa kluczowe: więzienie; służba więzienna; doktryna; transformacja; osadzony.

\section{EVOLUTION OF DEFENSIVE DOCTRINE - IMPOSED NECESSITY OR CONSCIOUS PROCESS OF HUMANIZATION}

\section{Summary}

The aim of the article is to analyze the contemporary doctrine of penitentiary system within the context of political transformation that took place in Poland in the early $90 \mathrm{~s}$. In particular, author suggests that while introducing the changes in the system, its dual nature should be considered, consisting of two main elements: detained individuals and custodians. The article highlights the main assumption of the modern penitentiary doctrine - the focus on humanitarian approach towards detained individuals, which should be reflected by the careful and selection of skilled and professional staff. The author highlighted main challenges that Polish penitentiary system faced during political and economic swift in the early 90 s, i.e. substantial redundancy, lack of resources, evolution of crime and perception of prison officers among society.

Key words: prison; prison officers; doctrine; transformation; convict. 